JOURNAL OF SECURITY AND SUSTAINABILITY ISSUES

ISSN 2029-7017 print/ISSN 2029-7025 online

2018 December Volume 8 Number 2

http://doi.org/10.9770/jssi.2018.8.2(8)

\title{
Scopus
}

\section{GLOBALISATION AND HEALTH SECURITY: A CASE STUDY OF DISTANT INDIVIDUALS' RISK PERCEPTIONS OF THE 2014 EBOLA OUTBREAK}

\author{
Jennifer Atu ${ }^{1}$, Cody Morris Paris ${ }^{2}$, Belisa Marochi ${ }^{3}$ \\ ${ }^{1,2,3}$ School of Law, Middlesex University Dubai, United Arab Emirates \\ ${ }^{2}$ University of Johannesburg, South Africa
}

Emails:. ${ }^{1}$ jenniferoatu@gmail.com, ${ }^{2}$ c.paris@mdx.ac.ae, ${ }^{3}$ b.marochi@mdx.ac.ae

Received 15 November 2017; accepted 20 October 2018; published 30 December 2018

\begin{abstract}
The wider awareness and recognition of human security threats has developed over the last several decades. Spurred on by globalization, greater human mobility, global media, economic interconnectedness and technological advancements, the securitization of non-military security threats have deepened and widened security discourses. The percieved risk posed by truly global threats have resulted in new international regimes and cooperation, national governments have reevaluated their national security strategies, and grassroots movements have revealed and mobileized individuals around the world to action. Global health security threats, and in particular, pandemic diseases, are one just one of many threats currently facing the global community that has the potential to envoke fear and feelings of insecurity and panic, particularly when securitized through twenty four hour news networks and social media. The purpose of this study is to explore the securitization process of a health security threat, the 2014 Ebola outbreak, and risk perceptions of individuals living in a global city geographically distant from the outbreak. This study reports the findings from interviews with eleven individuals based in the United Arab Emirates to explore their individual risk perceptions of the outbreak of the Ebola virus, and to understand how information about the outbreak was obtained, processed and consequently construed by these individuals. The findings suggested that with the increasing securitization of diseases, individual risk perceptions of the 2014 Ebola outbreak were a reflection of a variety of discourses concerning the security issue at the national and global levels. Therefore, in light of the increasing emergence and re-emergence of pandemic diseases and transborder global threats, it is important to consider individual perceptions of the threats and the influence of government, media (traditional and social media), and individual experiences in a global and interconnected world.
\end{abstract}

Keywords: Health Security; Globalisation; Securitization; Risk Perception; Pandemic; Human Security,

Reference to this paper should be made as follows: Atu, J.; Cody Morris Paris, C. M.; Marochi, B. 2018. Globalisation and health security: a case study of distant individual risk perceptions of the 2014 Ebola outbreak, Journal Security and Sustainability Issues, 8(2): 209-220. http://doi.org/10.9770/jssi.2018.8.2(8)

JEL Classifications: F01

\section{Introduction}

The $21^{\text {st }}$ century has seen the emergence and re-emergence of numerous threats to the security of human lives (Hough, 2018). Over the last few decades globalisation and technological innovations have spawned tremendous development and created an increasingly interconnected world. Transportation technologies, advancements of information and communication technology, global media, greater human mobility and tourism, interconnected economic markets have all transformed the world (Stojanov et al., 2011; Strielkowski, Rausser, 2013; Mikhaylov et al., 2018; Žižka et al., 2018; Nikitina et al., 2018; Tvaronavičienè, 2018; Fakhry et al., 2018). While many of these transformations have led to greater opportunity, wealth, and well-being, the last few decades have also seen the emergence of complex interconnected global security threats. Climate change, environmental degradation, natural disasters, pandemic disease, and threats to biodiversity are true global threats that are not contained within any national border. These are existential threats to both nations and individuals. 
The outbreak of communicable diseases such as Ebola (Kaner and Schaack, 2016) and Zika in 2014 and 2016, respectively, have broadened the discussions about the global management of threats to human and health security (McInnes and Roemer-Mahler, 2017). Nevertheless, governments have realised that are nearly powerlessness on their own to protect against the threats of pandemic outbreaks, and thus the threats are truly global in nature and require global collaboration. Additionally, given affects of globalization, individuals can be affected by both perceived and realized threats. Moreover, pandemic diseases and other health security threats, in particular, have been linked to human behaviour (Harris, 2017). Therefore it is important to ascertain people's perceptions of particular threats.

The outbreak of Ebola virus in 2014 in West Africa was reportedly the largest outbreak of the virus in history. The outbreak resulted in over 28,600 infectious cases and 11,325 deaths in the affected countries, in comparison to approximately 23,800 reported cases in the previous 20 outbreaks from the discovery of the virus in 1967 to 2013 (Laupland and Valiquette, 2014; CDC, 2018). Liberia, Sierra Leone, and Guinea were all finally declared Ebola-Free in 2016 (Kaner and Schaack, 2016). The outbreak prompted rapid national and international responses due to the perceived degree of threat the Virus posed. The international community began to reassess the impacts of diseases on human security. The United Nations Security Council (UNSC) called for an immediate response to the crisis to halt the "constituted threat to peace and security worldwide (UN, 2014)". Besides the evident prominent outbreak of Ebola virus in West African nations, the threat became undeniable to the global community. The scale of threat was visible by the reported Ebola cases in Europe, and eleven cases in the US (CDC, 2018).

The case of the Ebola outbreak illustrated how the challenges facing individual countries for combating global security threats. These threats cannot be addressed head-on militarily. Instead they must be understood through a wider and deeper conceptualization of security (Hough, 2018). Health-related threats of the Post-Cold war era were central to the emergence of the 'human security' concept. A key turning point in the discourse on 'health security' came on the $10^{\text {th }}$ January 2000, when the US Vice President, Al Gore in a speech to the United Nations Security Council suggested that contagious diseases such as AIDS, posed an exesential threat to global security, nations, and well-being of the people around the world (Jimba, 2012). This perspective has evolved during the past thirty years.

In 1983, a "theory of securitization' emerged from the Copenhagen School of Security Studies to help explain the process by which an issue is 'securitized' into an existential threat to security. The theory argues that the securitization process of an issue starts when a speech act, such as Al Gore's declaration of AIDS as a threat to human security, occurs. These speech acts are also subject to the perception of risks or threats. Buzan and Waever (2009) have shown that the securitization process begins with the appearance of perceived risk and/ or the fear towards a threat. In this study, we aimed to provide further insight into how global health security threats are perceived by individuals 'at a distance'. The aim was to explore the risk perceptions individuals of a health security threat, in this case, the 2014 Ebola Outbreak. The study explores linkages between the securitization process and risk perception theory to understand how perceptions related to the outbreak of Ebola are construed. The study employs a qualitative research design based on in-depth semi-structured interviews with individuals residing in the United Arab Emirates.

\section{Globalisation and Health Security}

The emergence of the concept of human security has widened and deepend the traditional conceptualization of security (Hough, 2018). The concept of Human Security cam be simply understood as "people's freedom from fear" (Gomez and Gasper, 2013). Moreover, the Commission of Human security have suggested that human security is the need to protect the vital core of all human lives in ways that enhances human freedoms and human fulfillment (OCHA, 2009).

Two prominent schools contributed to the emergence of the concept of human security: the narrow school and the development broad school. While the narrow school leaned towards a more traditional understanding 
of security, the development broad school argued that human security was to be concerned with more than traditional threats to humankind such as violence (Collins, 2013, p.106). In 1984, the World Health Organisation (WHO) began to frame global health issues as global security threats. The WHO defined global public health security as "the activities required, both proactive and reactive, to minimise vulnerability to acute public health events that endanger the collective health of populations living across geographical regions and international boundaries" (Chiu et al., 2009, p.680). The increased connectedness of the globalized world and emergence of a constant flow of information through around the clock global media and social media has resulted in "international anxiety about a host of potentially lethal 'rogue' viruses circulating the planet" (Collins, 2013, p.335).

In a globalised world, pandemic diseases are fast-moving, infectious and in many cases deadly. Despite the positive developments of globalisation such as technological advances, social media, and transportation systems, the negative side of globalisation is the speed and scale diseases can spread. The Ebola outbreak of 2014 resulted in global news coverage and increased concerns about the existential threat that the outbreak can have on the global community, states, and individuals. This anxiety has emerged in the face of other recent oubreaks. Outbreaks of SARS, West Nile Virus, Pandemic Influenza HIV/Aids are some of the cases that illustrate the potential threat of pandemic disease in an age of globalization, travel and trade. The gloal spread (although small in relative terms) of the 2014 outreak of the Ebola virus was to a great extent facilitated by the easy means of transportation, from one country to another.

Approximately one out of three annual deaths in the world is preventable with knowledge and resources (Chen and Narasimhan 2003). Means of communication such as news networks and social media enable the process of quickly sharing information throughout the world. This communication does not only spread the news faster but could help solve the problem faster. For example, in the early years of the 21 st century, the outbreak of SARS could have been rapidly contained with the effectiveness of information-sharing. However, the poor exchange of information between Chinese government, other neighboring countries, and international organisations led to, hundreds of reported cases, the spread of SARS to other continents, and at least five deaths (Hough, 2018).

States and organizations adopt different policies according to how a threat is perceived. The control of the Ebola Virus can be attributed to these exact advancements in technology, communication, and social media. For example, the global public health surveillance adopted by the WHO in 1995, used airport surveillances to attempt to control the rapid spread of diseases. Some other countries have immediately implemented a similar prevention policy by closing their borders to tourist entry, as was the case of North Korea (McKenzie and Park, 2014), and particularly to people arriving from Ebola-infected countries, as was the case of Australia (McKirdy, 2014).

As a result of the advancement of social media, information, and knowledge of particular threats, people's perceptions and actions are also influenced by the securitization processes. Furthermore, understanding risk perception is important to determine the precautions taken by individuals and the global community in taking the necessary actions to address the treats andnd miminize impacts of the threat. Therefore, the concept of security needs to be understood from multiple perspectives including that of individuals.

The case of the 2014 Ebola outbreak illustrated the importantns the media plays in transmitting knowledge about events and incidents thereby influencing individual perceptions of the world around them. As "uncertainty tends to breed anxiety" (Collins, 2013), fear over infectious diseases can lead to larger issues when not addressed or contained.

\section{Theoretical Framework for the Research}

Defining risk is difficult, and the concept reflects a range of understandings of anticipation, future, and destruction. Weinstein et al. (2007, p.146) and Douglass (cited in Joffe, 2003, p.56), for example, describe risk as " a judgment of the probability that harm will occur if no preventative action is taken..." and "danger from 
future damage." While discussing perceptions, Rushton (2011) suggests that not all infectious diseases are necessarily perceived as threats to health security. Thus, it is arguable that threats to health security are causal effects of the public and individual perceptions towards different diseases. This further leads to understanding that health security appears to be of a greater threat when no knowledge or control over the disease exists.

Risk perception arises from communications that can awaken fear in the receivers of the messages. According to Jeffries (2012), a growing body of literature revealed that the media plays an active role in creating "climates of fear" and thus structuring the culture of fear. Jeffries (2012) noted that that that "media fuelled the proliferation of irrational fears, is seen as a powerful force undermining people's capacity to grasp the difference between imagined fears and genuine threats" (p.40). Thereby stressing the importance of individual interpretations of an existential threat in the process of securitizing an issue is crucial.

While some scholars have argued that individuals are more at risk in the current society, other scholars recognize this process is constructed. Cebulla (2007, p.129) argued that "social institutions today no longer provide the protection, support, and solidarity enjoyed in the previous, modern era; and, as a result, uncertainty has come to permeate society and our view of the future," which further demonstrates why citizens might feel at risk. However, this explanation fails to reveal that the concept of risk is constructed.

Beck (1992) has highlighted three main observations of risk perception. First, that risk is always created and affected by social systems, such as the governmental institutions responsible for the securitising aspects that are threatening to human security. Second, as risks are created and affected by social systems, its magnitude ultimately depends on the quality of the social relations and processes in place that further securitize an issue of concern. Third, that the primary risk, in fact, is the social dependency of the society on the institutions responsible for effectively providing security measures to the public.

Sjoberg (2000, p.2), argues that risk arise for individuals in a "veritical manner" as the perceptions of people surface from indirect or direct experience. Arguably, the residual fear around the Ebola virus due to previous outbreaks and depiction in popular media, serves as indirect experience for the global community, thus increasing the level of fear towards being at risk of the virus. Recognizing that these perceptions of risk are connected to the concept of securitization is important.

An individual's perception is the result of one's interpretation of information and circumstance. Understanding how individual perceptions are formed is crucial to understanding the securitization process of health threats. Post-Structuralism is defined as the inquiry of meaning from different viewpoints (Besley, 2010). Therefore, examining risk perceptions and seucirty threats through a post-structuralist lens can provide insights into how risk perceptions and the securitization of perceived threats are constructed and performed.

Poststructuralists, such as Foucault and Derrida, argue security discourse "involved a shift from an objective conception of security where threats could be assessed, to a practice through which subjects were constituted" (Buzan and Hansen, 2009, p.142). Thus, approaching security studies from a Post-Structuralist perspective can explain how people make sense of their perceptions and how perceptions impact practices.

Post-structuralism can be used to reveal further risk perceptions, based on the realisation that different positions lead to different perceptions and consequent performances by people. To further elucidate the Post-Structuralist view and the importance of linguistic approaches in security studies, scholars argue language can influence social power (Hook, cited in Buzan and Hansen, 2009, p.141).

Sjoberg (2000, p.1.) explains that "risk is always construed", thus questioning the construction of fear perceptions that ultimately lead to securitization initiatives. This theory arises from the idea that an underlying structure, such as media or personal experience, is held responsible for the preconceived ideas that people obtain resulting in the perceptions of risk, and policy formulations thereafter. Understanding security from the Post-Structuralist view, therefore, provides a better basis for suggesting that there are numerous factors 
to put into consideration when attempting to understand the culture of fear, and consequently its effects on securitizing matters of concern.

Securitization Theory provides an explanation of how issues are securitized at the individual level and the global level, and provides an explanation of how perceived security threats (terrorism, nuclear war, etc) can differ from actualized threats to individual safety and security (accidents, poor diet, etc) (Buzan and Waever, 2009). Therefore, as outbreaks of diseases occur, the process of securing oneself is considered to be a macroSecuritization process at the individual level, while this plays a role in the securitization at the state or international level resulting from globalisation.

Borbeau (2014, p.189) defines securitization as "the process of integrating an issue into a security framework that emphasizes policing and defense". Securitization is the process by which a political issue evolves into a security threat due to an actor, through a "speech act", designates the issue poses an existential threat to a referent object Taureck (2006). The process of securitization is often initated by percieved fear towards an occurrence, or existing physical threat as conceived by a referent object, or in this case, a society (Williams, 2011, p.445).

Threats to security push institutions and individuals to the process of securitization. The outbreak of a disease encourages one to take personal precautions and pushes institutions to do the same. The case of Ebola in West Africa illustrates how individuals, governments, and the global community responded in different ways. Understanding the complexity of securitization is crucial in the context of health security. The Ebola virus was not a securitised issue on most national and international agendas in previous years and fast after the outbreak, risk perception led to a process of politicization and finally securitization in the global community.

The securitization spectrum (Collins, 2013) illustrates how an issue can evolve from a non-politicised to a politicized to a securitized issue. When an issue is non-politicized, fear perception can appear to be inherently almost non -existent. Following the spectrum, once a threat is politicized and becomes part of public policy, the issue is automatically included in the public debate, thus becoming a public discourse. Therefore, there are three phases of securitization:

a) The identification of an existential threat by an actor/ person to his/her existence,

b) The acceptance of the threat by a target audience, and

c) The reallocation of resources to combat such threats (Yuk-ping and Thomas, 2010).

Investigating how these phases of securitization play a part in health security is crucial to understand the role of fear and risk perception on the individual.

\section{Methods}

A qualitative interpretivist research approach (Bryman, 2012) was employed to understand how meaning is created in the social world and, in this case, how risk perceptions are constructed by individuals in the globalized world. The recent outbreak of the Ebola virus demonstrates that the process of securing the individual or the global community is driven by the forces of fear and what is perceived as a threat to human security. As Taureck (2006) has argued, security is a "social and intersubjective construction," thus this study seeks to examine how individuals perceive threats and personal risk to gain insight how issues are securitized at the individual level.

Eleven in-depth semi-structured interviews were conducted with residents of the United Arab Emirates. The United Arab Emirates is geographically central to the majority of the world's population. The expatriate resident population is made up of more than 200 nationalities and comprises approximately $80 \%$ of the total population. Additionally, Dubai and Abu Dhabi are leading tourism destinations. Dubai alone is set to receive more than 15 million international tourists and currently is the fourth most visited city in the world by international overnight visitors. 
Additionally, the UAE is home to the busiest airport in the world for international passenger traffic (Dubai International Airport), the future busiest airport in the world in total traffic (Al Maktoum International Airport), and is one of the world's leading shipping and logistics centers. As a global center of mobility, the UAE provides a unique context to explore the risk perceptions of the Ebola outbreak as it is both geographically distant from the outbreak of the Ebola virus in West Africa and cognitively and temporally proximate. With the numerous air connections, the UAE is one of the 'gateways' from West Africa to the world.

The participants (Table 1) for this study were selected purposively to include a wide range of the personal experiences and backgrounds. Some of the participants had some unique work experience that may orientate their perceived risk of the outbreak as a security threat: two participants work in the development sector, and another is a nurse, two are from Nigeria, one lived through the civil war in Yugoslavia, and several were university students. The participants are from a range of age groups and nationalities from West Africa, East Africa, Europe and the Asia Pacific.

Table 1. Participant profile

\begin{tabular}{|c|l|l|c|l|}
\hline No & \multicolumn{1}{|c|}{ Gender } & \multicolumn{1}{c|}{ Nationality } & Age & Occupation \\
\hline 1 & Female & Nigerian & $18-29$ & Nursery school teacher \\
\hline 2 & Male & Kenyan & $30-49$ & CEO of an NGO \\
\hline 3 & Female & British & $50+$ & Retired Nurse \\
\hline 4 & Male & Pakistan & $18-29$ & Unemployed \\
\hline 5 & Female & Pakistan & $18-29$ & University Student \\
\hline 6 & Female & Bangladesh & $18-29$ & PR representative \\
\hline 7 & Female & Australia & $18-29$ & University Student \\
\hline 8 & Male & Sudan & $18-29$ & Business Student \\
\hline 9 & Female & Serbia & $30-49$ & Consultant \\
\hline 10 & Male & Former Yugoslavia & $50+$ & Retired \\
\hline 11 & Male & Nigerian & $30-49$ & Real Estate agent \\
\hline
\end{tabular}

An interview guide with questions was designed to prompt discussions about risk perception, and health security was developed and used to ensure some continuity between interviews. However, to elicit more information based on the personal experiences of the participants, some questions were tailored to their professional or personal backgrounds. For example, one of the participants who is a retired nurse was asked about her opinion in regards to improvement of technology over the years and its relation to the evolving contemporary and future threats to health security. The interviews all took place in the United Arab Emirates, were face to face, and lasted between twenty minutes and one hour. All interviews were recorded and transcribed.

A multi-step abductive data analysis process was employed allowing for a theoretically informed analysis of the interview responses. An abductive approach is particularly appropriate for this case, as it allows the researcher to alternate between previous theory and empirical data (Alversoon and Skoldberg, 2017). This this cases, the analysis started with two overall pre-selected 'categories,' informed by the literature, Globalisation and Risk Perception. These were used to initially code passages of the transcripts. Next, the second round of coding was completed that focused on uncovering emergent themes within each of these two categories.

\section{Results and data analysis}

The analysis of the data resulted in five emergent themes. The following discussion examines each of these in more detail to uncover the influences on and impacts of individual's risk perceptions to a major health security event. The discussion is organized into two main categories: Globalisation and Risk Perspectives. 


\subsection{Globalisation}

\section{Geographical distance:}

The geographical locations of the Ebola outbreak combined with personal experiences impact the perception of the issue. Recognizing the potential health challenges of a large expatriate workforce, the United Arab Emirates requires a medical checkup, including a blood test and chest x-ray, as part of the approval process for resident visas. However, these tests only focus on several communicable diseases including HIV, tuberculosis, and Hepatitis. There is a clear perception of the UAE as a country concerned about health security (Health Authority Abu Dhabi (HAAD), (2015). However, in potential pandemic situations, these measures would not necessarily prevent the spread of a disease like Ebola. Instead, more drastic measures may be taken at points of entry reducing connectivity of transportation networks, and preparing the local health infrastructure. In the UAE, the local hospitals with containment facilities were told to be ready and on standby. At the airports, there were no mandatory screenings, as was the case in some European and American airports, but instead a careful eye for symptomatic passengers. Additionally, Emirates Airlines suspended flights to Conakry, Guinea (which were just resumed again in August 2016). The UAE's preventative and preparedness actions seem to have reduced the perceived risk of the Ebola outbreak to individuals in the UAE. The quote below illustrates this. Sudanese male participant, 21 years old stated: "I think when it was first coming out, I was a bit worried about how it would be contained because I wanted to go back to the UK. I had a good feeling that it wouldn't come to the UAE because they are very safe in that regards..."

As an emerging global hub, the country is, in fact, vulnerable to health security threats in other parts of the world. Previous outbreaks of Ebola have resulted in cases of the disease in the USA (1989, 1996,1999), Italy (1992), England (1976), and Russia (2004), with some of the countries reporting several human cases while others reported the presence of the virus in quarantined facilities by imported monkeys (CDC, 2015). Similarly, several countries outside of West Africa had confirmed human cases during this most recent outbreak, and most of these were from people who recently traveled from West Africa. Thus, for some respondents, the perceived risk was not of Ebola coming to the UAE, but the risk of traveling. Pakistani male Participant, 26 years old: "Because of the country's jurisdiction and government being very strict about the security status of the country I do not feel at risk... So I feel at risk to travel, and I have made a decision not to travel."

Several of the respondents' concerns highlighted the role of location and proximity to the disease in their perception of risk posed by the outbreak.

\section{Media Interaction and Formation of Perceptions:}

The importance of media in opinion formation is critical. News reported by media gains momentum depending on its relevance, its impact and the language used in the transmission of the information. The study has shown that the following descriptions of Ebola Virus given by the participants are related to descriptive words such as "deadly" and "uncontrollable," given in various news sources they engage on. Thereby further suggesting the need to consider "language games" in the formation of perceptions as suggested by critical constructivists (Buzan and Hansen, 2009 p.199). For further demonstration, another participant also goes on to explain that "It's a rather death sentence of a disease..."However, it could be related to prior experience or prior knowledge they had obtained as explained by a male, Kenyan-Pakistani participant aged 30-35, working in the development sector: "I think there are a couple of movies in the 90's, 'The outbreak' is one of them. I think Ebola has always had this kind of fascination, like the most deadly virus. So I think it was already in the public consciousness it is not new. So when this outbreak happened, it's because it's the biggest outbreak of this deadly disease, and it's often being misunderstood."

Despite this negative description of what Ebola represents, the concept of fear is not formed into a particular feeling as people appear to pay more attention to other daily risks. British female participant, 52 years: "I am more worried about getting hit by a taxi driving in the UAE, I am more likely to die that way" as opposed to getting infected by the Ebola virus... We know there is always a risk of it [Ebola virus], every time you get in a plane there will be a slight minimum risk of getting any disease..." 
The respondent perceives the personal threat to be small but the global threat to be larger. This interviewee does not perceive the outbreak of the virus as an existential threat to individuals' level and is rather focused on other daily security perceived risks.

Securitization theory suggests that for an issue to be securitised, policy has to adapt to the threat. The way a country portrays its security system has an impact on the perceptions of people. For example, the perception of all participants based on their health- security in the UAE (strictly based on the outbreak of Ebola) was rather positive.

On the other hand, while most of the participants, perceived the media as "fear mongering," a 60-65 year old, male participant, from the former Yugoslavia, identified the media of today as putting more efforts to inform people in comparison to the 60 's, in which other outbreaks occurred.

\section{Global Advancements}

Despite innovations in medicine and technological advancements around the world, pandemic diseases remain one of the most serious global security threats facing individuals and states around the world. The increased global mobility of goods and people, interconnected global transportation and logistics networks, international norms, and increasing regionalization and loosing of border restrictions in some parts of the world can all exacerbate the destructive potential of pandemic diseases. This was illustrated by the recent Ebola outbreak where these advancements arguably contributed to the spread of disease (even if just a few cases) to other continents. It is these discourses, explained by the participants that show that as time and technologies advance, there is an increasing drive to understand not just the events that happen around the world but the reason why they happen. Through understanding these events, one can take personal measures towards security. Nigerian female participant, Aged 21: "Globalisation has been causing this much damage to the earth ...because of this climate change we are getting a lot of these diseases that we never even had before. So a lot of people have associated the change in atmosphere to change in certain viral strains to cause diseases and sicknesses to people. So, when you say is health security being threatened, indirectly yes by globalisation."

As illustrated by this comment, the participant's makes a clear connection between the contemporary complexities of globalization and the potential risk associated with it, in this case framing health security (in situations like the Ebola outbreak) within broader issues of climate change and globalization. This discourse, as stated by this participant (and also appears in some of the other interview exchanges), suggests that individuals are affected by their perception of globalization, which in turn frames their perceptions of risk. Furthermore, there is a historical dimension to consider. Win the case of Ebola, there have been several outbreaks since 1967, however only two of the participants knew about these outbreaks. With global advancements in information and communication technologies, a twenty four hour global news media, social media, and increased numbers of individuals living outside of their country of citizenship, it is clear that the transmission of information is faster and can have a greater impact on how perceptions of risk are constructed, and how an issue may be securitisatized at the individual, national and global levels.

\subsection{Risk Perspectives}

Impacts of perception on securitization:

The portrayal of Ebola Virus as an "African disease" has impact on the response on security threats. Some participants demonstrated their surprise to the slow response from the international community towards the affected African countries. Some went as far as comparing the response given to African countries, to the response provided to the few cases in the US and Spain. Nigerian Male, Participant aged 33: "The media makes everything sound very bad. They make it sound like once you go to Africa, or once you get on a plane you could just get infected with Ebola. It was that bad... [And] it made me feel like I needed some hand sanitizer..." Australian female participant aged 32: "I think, because some government were slow to respond, so I think what it means is that people are focused on things like terrorism, and actually you could be sitting in a plane next to someone who could be very very sick, and actually, that's just as dangerous if not more. So I think that global health security, there may be a need to pay more attention to that. Like if this is contained, maybe they 
should still keep the screening at the airport. And maybe pay closer attention to help people out."

These quotes show that the response to a threat, to a great extent, is dependent on what actors perceive as a threat. Additionally, although existing risks can be perceived as threats, it is the level of fear towards the threat that determines the urgency of securitizing the existing threat. Similarly, Pain (2009), discusses the culture of risk in western societies, as the content in which 'new' threats have emerged, thus, arguably, a governmental response can be correlated to the perception of risk.

\section{Global Politics perspectives:}

The role of politics, from the transmission of diseases to how these are dealt with by different actors, is an important factor to participation. Some participants implied certain information was not provided to the public thereby implying that this outbreak could somewhat related to bioterrorism. Serbian Female participant aged 35: "HIV has been there for a very long time, and could it be that something happened to the virus? So if it is bioterrorism, the virus has been adjusted..., to spread faster and to have greater effect. If the virus is spreading in its natural way, I don't have an explanation. Because if it was there before, and it was spreading, and it was contained, why are we not using the same tools? So if it was effective 30, 40, 20, 10 years ago, why is it that now, in 2015 with all the advancement that we have got in the meantime, we can't contain it?"

Participants seek to understand the factors that play a role in formulating their opinions. Among the participants there appeared to be an underlying belief that this outbreak was not a global outbreak as it spread mostly across West African countries, and only a few cases were recorded in the global north. Participants also claimed that the outbreak was rather "localised" (Participant 10) or "Urbanised" (Participant 2). Nonetheless, it can well be considered a globalized issue, as events in one part of the world can significantly impact countries far away (Cohn, 2008) especially in today's global political economy.

The table 2 below shows whether the participants identify the outbreak as a means to take personal precautions or simply as a global issue which has no direct impact on them.

Table 2. Participant threat identification.

\begin{tabular}{|c|c|c|c|}
\hline \multirow[b]{2}{*}{ Participant } & \multicolumn{2}{|c|}{ Threat identification } & \multirow[t]{2}{*}{ Example } \\
\hline & Individual & Global & \\
\hline 1 & $\mathrm{X}$ & & Changes in travelling plans to Nigeria. \\
\hline 2 & & $\mathrm{X}$ & $\begin{array}{l}\text { Recognition of global crisis } \\
\text { No personal reaction }\end{array}$ \\
\hline 3 & & $\mathrm{X}$ & More preoccupied with daily risks. E.g., having an accident. \\
\hline 4 & & & Not aware of the extent of the threat posed by Ebola. \\
\hline 5 & $\mathrm{X}$ & $\mathrm{X}$ & A feeling of risk, recognition of disease transmission from one country to the other \\
\hline 6 & & $\mathrm{X}$ & $\begin{array}{l}\text { No fears towards the disease at the individual level. } \\
\text { Recognises the threat when considering travelling. }\end{array}$ \\
\hline 7 & $\mathrm{X}$ & $\mathrm{X}$ & Acquaintance affected with Ebola, and recognize threat at a global and personal scale. \\
\hline 8 & & $\mathrm{X}$ & Identifies the outbreak as a global social problem, but not as a personal threat. \\
\hline 9 & $\mathrm{X}$ & & Personal precautions are taken: e.g., use of Hand sanitizers \\
\hline 10 & $\mathrm{X}$ & $\mathrm{X}$ & Changes in travelling plans, and recognition of the scale of the threat to the global community \\
\hline 11 & & $\mathrm{X}$ & Does not have an opinion on the outbreak of the virus \\
\hline
\end{tabular}

As observed, the table above shows that only 5 out of the 11 participants are fearful of Ebola at the individual level. Few personal precautions are undertaken. On the other hand, all participants identify Ebola as a global problem and or simply do not have an opinion about the possible effects of the outbreak. In summary, the perceptions formed by the participants of this study, are influenced by the media, the policies in the country of residence, and these set of factors are components of their discourses relating to health security. Residents in the UAE, feel to a great extent secure and not- vulnerable to the global health threats of Ebola. Recognizing personal opinion formation plays a role in adaptability to securitization measures or global health-related policies is important. Perceptions, therefore, can impact individuals differently and influence various performances. 


\section{Conclusion}

Individual perceptions do impact how individuals make sense of the information and circumstances of a potential health security threat. Where wars and military threats were previously the most framed as the most pressing security issues, additional threats have are now commonly, and rightly so, framed as emergent threats. In the case we examined her, the potential for pandemic spread of a severe disease like Ebola is a cause for concern for individuals, states and globally. Diseases can now be tools used in wars for bioterrorist attacks (Teckman, 2013) or naturally occurring pandemics. The attention from the international community towards health security is quite new (since the widening of the concept of security in the 1990s), but the need for action and preparedness to address health security issues has been clearly and loudly articulated by government, the private sector, military, and civil society leaders. Policy implementations and preparedness simulations are difficult to put into practice if the understanding of risk perceptions of people at the individual level are not fully considered.

To understand the securitization of health in the outbreak of Ebola context, this article explored how people make sense of their security situation and how their perception of risk could influence their actions. Interviews with residents of the UAE regarding the 2014 outbreak of Ebola show that the individuals make sense of securitization processes in various ways. The results reveal how risk perceptions and discourses are formed around and to these perceptions can impact individual security agendas. This study also found that globalisation, media and mobility all work together in framing the lens through which individuals, states, and the world perceive security threats

\section{References}

Ali, S. and Kelly, M. (2012). Ethics and Social Research' in Seale C. (ed.) Researching Society and Culture. Los Angeles: Sage.

Alvesson, M. and Skoldberg, K. (2017). Reflexive Methodology: New Vistas in Qualitative Research. London: Sage.

Beck, U. (1992). Risk Society, Towards a New Modernity. London: Sage publications.

Besley, C. (2010). Postructuralism in (Kuper, A. and Kuper, J.) (ed.)The Social Science Encyclopedia. London: Routledge pp.781-782.

Borbeau, P. (2014). Moving Forward Together: Logics of the Securtisation Process. Millennium- Journal of International Studies 43(187): 187- 206. https://doi.org/10.1177/0305829814541504

Bryman A. (2012) Social Research Methods $4^{\text {th }}$ Edn. New York: Oxford University Press.

Buzan and Waever. (2009). Macro-Securitization and Secvurity Constellations: Reconsidering Scale in Securitization Theory. Review of International Studies 35: 253-276. https://doi.org/10.1017/S0260210509008511

Buzan, B. and Hansen, L. (2009). The International Security Studies. Cambridge: Cambridge University Press.

CDC. (2015). Ebola (Ebola Virus Disease). Outbreaks Chronology: Ebola virus disease. Available at: http://www.cdc.gov/vhf/ebola/ outbreaks/history/chronology.html

Cebulla, A. (2007). Class or Individual? A Test of the Nature of Risk Perceptions and the Individualisation Thesis of Risk Society Theory. Journal of Risk Research 10(2): 129-148.

Chiu, Y.et al. (2009). The Nature of International Health Security. Asia Pac J Clin Nutr. 18(4): 679-683. https://www.ncbi.nlm.nih.gov/ pubmed/19965365

Collins, A. (2013). Contemporary Security Studies. $3^{\text {rd }}$ Edn. United Kingdom: Oxford University Press

Cresswell J.W. (2009) $3^{\text {rd }}$ Ed. Research Design: Qualitative, Quantitative and Mixed Methods Approaches. Los Angeles: Sage.

Edkins, J. (2007). 'Post-Structuralism' in Griffiths, M., International Relations Theory for the Twenty-First Century, An Introduction. London: Routledge.

Foucault, M. (1972). 'The Unities of Discourse', The Archeology of Knowledge of Knowledge. Routledge. http://passthrough.fwnotify. net/download/584562/http://monoskop.org/images/9/90/Foucault_Michel_Archaeology_of_Knowledge.pdf 
Fakhry, B.; Aktan, B., Masood, O., Tvaronavičienė, M., Celik, S. (2018). The impact of a recent natural disaster on the Japanese financial markets: empirical evidenece. Journal of Competitiveness 10(2): 56-71 https://doi.org/10.7441/joc.2018.02.04

Gomez, O., Gasper, D. (n.d.) Human Security: A Thematic Guidance Note for Regional and National Human Development Report Teams. UNDP. http://hdr.undp.org/sites/default/files/human_security_guidance_note_r-nhdrs.pdf

Harris, B. (2017). The world's biggest killers? Diseases linked to human behaviour. World Economic Forum. Available at: https://www. weforum.org/agenda/2017/10/the-world-s-biggest-killers-diseases-linked-to-human-behaviour/

Hough, P. (2018). Understanding Global Security. 4th Edn. London: Routledge.

Jeffries, F. (2012). Mediating Fear. Global Media and Communication 9(1): 37-52. https://doi.org/10.1177/1742766512463039

Joffe, H. (2003). Risk: From Perception to Social Representation. British Journal of Social Psychology 42: 53-73. https://doi. org/10.1348/014466603763276126

Kaner, J. and Schaack, S. (2016). Understanding Ebola: the 2014 epidemic. Globalization and Health, 12(53): 1-7. https://doi. org/10.1186/s12992-016-0194-4

Kay, S. (2008) 'Global Security' in Snaar, T. and Snaar, D. (ed) Introducing Global Issues $4^{\text {th }}$ Edn. United States: Lynne Reinner Publishers, Inc.

Laupland, K. and Valiquette, L. (2014). Adult Infectious Diseases Notes: Ebola Virus Disease. Canadian Journal of Infectious Diseases and Medical Microbiology 25(3): 128-129. http://dx.doi.org/10.1155/2014/527378

McInnes, C. and Rushton, S. (2012). HIV/AIS and Securitization theory. European Journal of International Relations. https://doi. org/10.1177/1354066111425258

McInnes, C., and Roemer-Mahler, A. (2017) From Security to Risk: Reframing Global Health Threats. International Affrairs, 93(1): 1313-1337. https://doi.org/10.1093/ia/iix187

Mckenzie D., and Park, M. (2014). North Korea restricting tourism because of Ebola Fears, Tour Group Says. Available at: http:// edition.cnn.com/2014/10/24/world/asia/ebola-north-korea-tourist-closure/

McKirdy, E. (2014). Australia instigates Ebola-Prompted Ban on Travel from West Africa. Available at:http://edition.cnn.com/2014/10/28/ world/asia/australia-immigration-policy-ebola/

Mikhaylov, A.S., Mikhaylova A.A., Savchina, O.V. (2018). Innovation security of cross-border innovative milieus. Entrepreneurship and Sustainability Issues 6(2): 754-766. http://doi.org/10.9770/jesi.2018.6.2(19)

Mishenin, Y, Koblianska, I,, Medvid, V., Maistrenko, Y. (2018). Sustainable regional development policy formation: role of industrial ecology and logistics. Enterpreneurship and Sustainability Issues 6(1): 329-341. http://doi.org/10.9770/jesi.2018.6.1(20)

Nikitina, M.G.; Pobirchenko, V.V.; Shutaieva, E.A.; Karlova, A.I. (2018). The investment component in a nation's economic security: the case of the Russian Federation. Entrepreneurship and Sustainability Issues 6(2): 958-967. http://doi.org/10.9770/jesi.2018.6.2(32)

Office for the Coordination of Humanitarian Affairs (OCHA). (2009). Human Security in Theory and Practice: Application of the Human Security Concept and the United Nations Trust Fund for Human Security. United Nations. https:/www.unocha.org/sites/dms/HSU/ Publications\%20and\%20Products/Human\%20Security\%20Tools/Human\%20Security\%20in\%20Theory\%20and\%20Practice \%20 English.pdf

Pain, R. (2009). Globalized Fear? Towards Emotional Geopolitics. Progress in Human Security, 33(4): 466-486. https://doi. org/10.1177/0309132508104994

Rivas, C. (2012) 'Coding and analisying qualitative data' in Seale C.(ed.) Researching Society and Culture: Sage: Los Angeles. Chapter 21

Rushton, S. (2011). Global Health Security: Security for Whom? Security from What? Political Studies. 59: 779-796. https://doi. org/10.1111/j.1467-9248.2011.00919.x

Samimian-Darash, L. (2011). Governing Through Time: Preparing for Future Threats to Health and Security. Sociology of Health \& Illness 33(6): 930-945. https://doi.org/10.1111/j.1467-9566.2011.01340.x

Sjoberg, L. (2000). Factors in Risk Perception. Risk Analysis, 20(1): 1-11. https://doi.org/10.1111/0272-4332.00001 
Statista (2015) Number of International Overnight Visitors to Dubai from 2010 to 2014 (in millions). Available at: http://www.statista. com/statistics/284636/visitor-arrivals-in-dubai-from-international-destinations/

Stojanov, R.; Strielkowski, W.; Drbohlav, D. 2011. Labour migration and remittances: current trends in times of economic recession, Geografie 116(4): 375-400.

Strielkowski, W.; Rausser, G. 2013. International Labour Migration and Structural Channels: A Case Study of Ukrainian Working Migrants in the Czech Republic, Ekonomicky Casopis 61(10): 1034-1052 https://www.sav.sk/journals/uploads/0621140410\%2013\%20 Strielkowski-Rausser-RS.pdf

Taureck, R. (2006). Securitization Theory and Security Studies. Journal of International Relations and Development 9: 53-61. http:// dx.doi.org/10.1057/palgrave.jird.1800072

Teckman, A. (2013). The Bioterrorist Threat of Ebola in East Africa and Implications for Global Health and Security. Global Policy Essay. https://www.globalpolicyjournal.com/sites/default/files/Teckman\%20-\%20The\%20Bioterrorist $\% 20$ Threat $\% 20$ of $\% 20$ Ebola $\% 20$ 05.13.pdf

Tvaronavičienè, M. (2018). Toward efficient policy making: forecasts of vulnerability to external global threats, Journal of Security and Sustainability Issues 7(3): 591-600. https://doi.org/10.9770/jssi.2018.7.3(18)

US Department of State. (2009). Remarks as Prepared for Delivery by Vice President Al Gore. U.N. Security Council Session on AIDS in Africa. Available at: http://www.state.gov/1997-2001-NOPDFS/global/oes/health/000110_gore_hiv-aids.html (Accessed 10th April, 2015)

Weinstein, N. et al. (2007). Risk Perceptions: Assessment and Relationship to Influenza Vaccination. Health Psychology 26(2): 146-151. https://doi.org/10.1037/0278-6133.26.2.146

Williams, M. (2011). Words, Images, Enemies: Securitization and International Politics. International Studies Quarterly 47: 511 - 531. https://doi.org/10.1046/j.0020-8833.2003.00277.x

World Health Organization (WHO). (2018). The top 10 Causes of Death. WHO. Available at: http://www.who.int/news-room/factsheets/detail/the-top-10-causes-of-death

Yuk-ping, C., Thomas, N. (2010). How is Health a Security Issue? Politics, Responses, and Issues. Health Policy and Planning 25: 447453. https://doi.org/10.1093/heapol/czq063

Žižka, M., Valentová, V. H., Pelloneová, N., Štichhauerová, E. (2018). The effect of clusters on the innovation performance of enterprises: traditional vs new industries, Entrepreneurship and Sustainability Issues 5(4): 780-794. https://doi.org/10.9770/jesi.2018.5.4(6)

Jennifer O. ATU is a research analyst associate. She holds a B.A. Honours degree in International Development from Middlesex University and LLM degree in Diplomacy and International Law from Lancaster University. Her research has been recognized with the Geoffrey Gullet Memorial Prize for the best undergraduate dissertation in international development and geographical studies and 1st place award in the 3rd United Arab Emirates (National) Undergraduate Research Competition. Her research interests include: social development in West Africa, global health governance, the role of securitization in global governance.

Dr. Cody Morris PARIS is the Deputy Director of Middlesex University Dubai and an Associate Professor in the School of Law and the Business School. He is a Senior Research Fellow with the University of Johannesburg. He holds a PhD in Community Resource Development, a MSc in Tourism Studies and a BIS in International Geography and Political Science with minors in Cultural Anthropology and Tourism from Arizona State University, USA. Cody is a social scientist with varied research and teaching interests within the areas of: Tourism, Mobilities, International Politics, Community Development, Sustainable Development, Technology, Global Security, and Experiential Learning.

Dr. Belisa MAROCHI is a Senior Lecturer in International Relations and the Head of the Institute of Sustainable Development at Middlesex University Dubai in the United Arab Emirates. After completing her MA in Political Science from the University of North Carolina at Chapel Hill in the US, she received a PhD in Social Sciences from Roskilde University in Denmark and University of Birmingham in the UK. Belisa also has a BA in Global Studies with a Middle East emphasis from University of California at Santa Barbara. Her research primarily focuses on inclusion, regionalism and collaborative governance. 